\title{
Research advances in animal distant hybridization
}

\author{
ZHANG ZhuoHui ${ }^{\dagger}$, CHEN Jie ${ }^{\dagger}$, LI Ling, TAO Min, ZHANG Chun, QIN QinBo, XIAO Jun, \\ LIU Yun \& LIU ShaoJun* \\ Key Laboratory of Protein Chemistry and Fish Developmental Biology of Ministry of Education, College of Life Sciences, Hunan Normal \\ University, Changsha 410081, China
}

Received February 17, 2014; accepted July 3, 2014; published online August 1, 2014

\begin{abstract}
Distant hybridization refers to crosses between two different species or higher-ranking taxa that enables interspecific genome transfer and leads to changes in phenotypes and genotypes of the resulting progeny. If progeny derived from distant hybridization are bisexual and fertile, they can form a hybrid lineage through self-mating, with major implications for evolutionary biology, genetics, and breeding. Here, we review and summarize the published literature, and present our results on fish distant hybridization. Relevant problems involving distant hybridization between orders, families, subfamilies, genera, and species of animals are introduced and discussed, with an additional focus on fish distant hybrid lineages, genetic variation, patterns, and applications. Our review serves as a useful reference for evolutionary biology research and animal genetic breeding.
\end{abstract}

distant hybridization, lineage, tetraploid, triploid, genetic breeding, application

Citation: Zhang ZH, Chen J, Li L, Tao M, Zhang C, Qin QB, Xiao J, Liu Y, Liu SJ. Research advances in animal distant hybridization. Sci China Life Sci, 2014, 57: 889-902, doi: 10.1007/s11427-014-4707-1

Distant hybridization, defined as a cross between two different species or higher-ranking taxa, facilitates the transfer of genomes between species and gives rise to phenotypic and genotypic changes in the resulting progeny. With respect to genotype, distant hybridization leads to genomelevel changes, such as the production of diploid, triploid, and tetraploid offspring. In addition, sub-genome level changes occur, as in the natural formation of minichromosomes in gynogenetic diploid progeny. At the DNA level, distant hybridization leads to the emergence of recombinant DNA variation in the offspring. With regard to phenotype, distant hybridization integrates the advantages of both parents, so that heterosis of growth rate, survival, disease resistance, and other traits is exhibited by future generations [1].

Many bisexual, fertile, stable allopolyploids have been

$\dagger$ Contributed equally to this work

*Corresponding author (email: 1sj@hunnu.edu.cn) obtained by interspecific hybridization in plants, including allotetraploid Raphano brassica formed by chromosome doubling and allohexaploid Triticum aestivum generated by crossing [2]. Researchers have inferred that gibel carp (Carassius auratus gibelio) has experienced successive rounds of genome polyploidization and recent genome duplication, leading to multiple genomes that point to its genetic origin. In addition, gibel carp are in the process of diploidization, as demonstrated by the presence of gibel carp genomic or subgenomic infiltration and the artificial generation of allopolyploids with integrated exogenous genes or genomes [3]. Diploid, triploid, and tetraploid crucian carp have been proven to exist under natural conditions [4]. An increasing number of studies indicate that polyploid fish evolution is associated with distant hybridization [5-7]. Hybridization has been shown to favor the formation and evolutionary radiation of species, with hybrid allopolyploidization potentially driving new species occurrence [8,9]. It is possible, however, that progeny of distant hybridization 
may contain genomes from different species, and that this process is a source of gene recombination and communication between different species. Lineages derived from normal distant hybridization may possess unprecedented new variations, and may even represent new species.

We introduce and review recent literature on distant hybridization in animals. We focus on fish distant hybridization, including fertile lineage formation and genetic variation, underlying mechanisms, and practical applications. This overview may serve as a useful reference for future in-depth animal hybridization research.

\section{Animal distant hybridization profile}

\subsection{Inter-phylum hybridization}

Examples of hybridization between different phyla include separate crosses of the sea urchin Anthocidaris crassispina (우) of Echinodermata with mollusks Acmaea nanshaensis $\left(\sigma^{\top}\right)$ and Mytilus edulis ( $\left.\sigma^{\top}\right)$ and the annelid Nereis succinea (ठ). Larvae of all three hybrids are similar to those of Anthocidaris crassispina. Although sperm from the male parent is introduced into the egg, distant male and female nuclear fusion is difficult. Because the male chromosomes are eventually degraded, they are not incorporated into the next generation's nuclei. The hybrid larvae thus resemble the larvae of Anthocidaris crassispina, the maternal parent [10].

\subsection{Hybridization between classes}

Inter-class hybridization has been observed in Asteroidea between Anthocidaris crassispina (우) and Craspidaster hesperus $\left({ }^{\star}\right)$, with the resulting larval offspring resembling the maternal parent [11].

\subsection{Hybridization between orders}

Hatched fingerlings have been observed from crosses between Megalobrama amblycephala (우) of Cypriniformes and Siniperca chuatsi ( $\left.\sigma^{\star}\right)$ of Perciformes [12], and between Hypophthalmichthys molitrix (우) of Cypriniformes and Pagrosomus major (o) of Perciformes [13].

\subsection{Inter-familial hybridization}

Inter-familial hybridization has been reported between perciform cichlids Oreochromis aureus (우) and Siniperca chuatsi $\left({ }^{\top}\right)$, with fingerling survival rates of $0.3 \%-0.5 \%$ recorded $[14,15]$.

Within amphibians, Hyla arborea (우) in southern France can hybridize with Pelobates cultripes ( $\left.\sigma^{\top}\right)$. A few of the resulting hybrids, all resembling Hyla arborea, can undergo metamorphosis. Hybridization has also been reported between Hyla arborea (우) and Bufo calamita ( $\left.\sigma^{\top}\right)$. In that case, the male parental chromosomes were expelled and did not participate in embryonic development, and relatively good development of hybrid offspring subsequently took place [16]. In contrast, most Bufo calamita (우) $\times$ Hyla arborea ( $\left.\sigma^{\top}\right)$ embryos died during blastocyst and gastrula stages, with only a handful of tadpoles, all morphologically similar to the maternal parent, reaching metamorphosis. These hybrids all have two sets of chromosomes [10].

No reports of hybridization between phyla, classes, orders, or families exist in which the $F_{1}$ progeny consist of both male and female bisexual fertile individuals. The absence of such self-crossing lineages implies that they cannot be formed through distant hybridization between such taxonomically divergent species. Here, the term "distant hybrid lineage" refers to lineages in which $\mathrm{F}_{1}$ hybrids from distant hybridization are able to form $\mathrm{F}_{2}$ and subsequent generations.

\subsection{Hybridization between subfamilies}

In fish, examples exist of hybridization between different carp subfamilies: Aristichthys nobilis (우)×Megalobrama amblycephala $\left(\sigma^{\star}\right)$ and its inverse cross [17], Aristichthys nobilis $($ 우 $) \times$ Ctenopharyngodon idellus $\left({ }^{\top}\right)$ and its inverse cross [18,19], Ctenopharyngodon idellus ( 우 )×Megalobrama amblycephala (ठ) (GB) [20], Ctenopharyngodon idellus (우)×Hypophthalmichthys molitrix ( $\left.\sigma^{\top}\right)$ and its inverse cross [17], Ctenopharyngodon idellus (우) $\times$ Cyprinus carpio (ठ) [17,21], Ctenopharyngodon idellus (우) $\times$ Megalobrama terminalis (ठ) [22,23], Mylopharyngodon piceus (우) $\times$ Megalobrama terminalis ( $\left.\sigma^{\top}\right)$ [24,25], Cyprinus carpio var. xingguonensis ( 우) $\times$ Ctenopharyngodon idellus (ð) [26-29], Hypophthalmichthys molitrix (우)×Megalobrama amblycephala $\left(\delta^{\top}\right)$ and its inverse cross [17,30,31], Hypophthalmichthys molitrix (우)×Xenocypris davidi (ठ) [32], and Cyprinus carpio (우) $\times$ Hypophthalmichthys molitrix ( $\left.\sigma^{\top}\right)$ and its inverse cross [33,34].

No naturally occurring lineages derived from fish subfamily crosses are known to exist. In our laboratory, Carassius auratus red var. (우)×Megalobrama amblycephala (ठ) (RB) [35] as well as Megalobrama amblycephala (우)×Xenocypris davidi ( $\left.\sigma^{\star}\right)$ formed distant hybrid lineages [36], and genetic variation characteristic of autotetraploid fish lineages was observed in Carassius auratus red var. (우)×Megalobrama amblycephala (ठ) hybrids.

\subsection{Hybridization between genera}

Examples of intergeneric hybrids in birds include Gus gallus ( 우) $\times$ Phasianus colchicus (ठ) [10], Gus gallus (우) $\times$ Pavo cristatus (ठ) [10], Numida meleagris (우) $\times$ Pavo

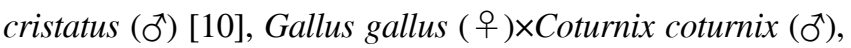
Tetrao urogallus (우) $\times$ Lyrurus tetrix (ठ) [10], Numida 
meleagris (우) $\times$ Gus gallus (ㅈ) [10], Cairina moschata

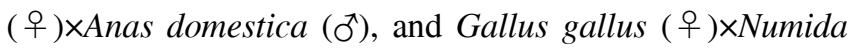
meleagris (ठ) [37].

Antelope-cattle hybridization is an example of crossing between different genera of mammals. The eland antelope (Taurotragus oryx), weighing up to $700 \mathrm{~kg}$, belongs to the sheep and goat even-toed ungulate subfamily. It has been hybridized with bovine, including cattle (Bos taurus), but the resulting hybrids are sterile [38]. Goats (Capra hircus) and sheep (Ovis aries), which belong to different genera, can form hybrids naturally or through artificial insemination. For example, a living hybrid was obtained from a goat (Capra hircus, 우) $\times$ sheep (Ovis aries, $0^{\top}$ ) cross in France in 1948 [39]. Since 1953, Bulgarian breeders have been producing viable sheep and goat hybrids; hybrid ewes have even borne a second generation, but hybrid rams are sterile [40].

A single individual produced from a cross between camel (Camelus ferus) and the South American llama (Lama glama) using artificial insemination was born in a Dubai camel breeding center in 1995. This hybrid camel had ears that were intermediate in length compared with its parents. It had a long tail and strong legs adapted for desert travel, like a camel, and lacked a hump and had fluffy hair, similar to its llama parent.

Examples of hybridization between fish genera are Carassius auratus red var. (우)×Cyprinus carpio xiangjiangnensis (ठ) (RC) [1,41,42], Carassius auratus gibelio (우) $\times$ Cyprinus carpio var. xingguonensis (ठ) [43], Hypophthalmichthys molitrix (우)×Aristichthys nobilis ( $\left(^{\star}\right)$ and its inverse cross [17,44,45], Parabramis pekinensis (우) $\times$ Megalobrama terminalis (ठ) [46,47], Megalobrama amblycephala (우)×Parabramis pekinensis (ठ) [48,49], Mylopharyngodon piceus (우) $\times$ Ctenopharyngodon idellus (ठ) [50,51], Rhabdosargus sarba (우) $\times$ Pagrosomus major (ठ) $[52,53]$, Sparus latus (우) $\times$ Rhabdosargus sarba (ठ) [53], Rhabdosargus sarba (우)×Sparus macrocephalus (ठ) [53], Plagiognathops microlepis (우) $\times$ Xenocypris davidi (ð⿱) [54], and Cirrhinus molitorella (우) $\times$ Sinilabeo decorus tungting $\left({ }^{\top}\right)[55,56]$.

In our laboratory, we obtained $\mathrm{F}_{2}$ hybrids and subsequent generations from distant hybridization of Carassius auratus red var. (우) $\times$ Cyprinus carpio xiangjiangnensis (o) [41], Cyprinus carpio (우) $\times$ Carassius auratus red var. (ठ) (CR) (data not published), Megalobrama amblycephala (우)× Erythroculter ilishaeformis (ठ) (BT) [1], and Erythroculter ilishaeformis (우)×Megalobrama amblycephala (ठ) (TB) (data not published). We have developed allotetraploid (4nAT) hybrid lineages from Carassius auratus red var. (우) $\times$ Cyprinus carpio xiangjiangnensis $\left(\sigma^{\star}\right)$.

A research team led by Professor Li Sifa at Shanghai Ocean University obtained fertile $F_{1}$ hybrids from distant hybridization between direct and reciprocal crosses of tilapia Oreochromis niloticus Yoshitomi lineage (우) $\times$ Sarotherodon melanotheron $\left(\sigma^{\star}\right)$. The $\mathrm{F}_{1}$ hybrids were then used to generate $\mathrm{F}_{2}$ offspring [57].

\subsection{Interspecific hybridization}

Chlamys farreri (우), a type of scallop, has been crossfertilized with Chlamys nobilis $\left(\sigma^{\top}\right)$ to obtain hybrid $\mathrm{F}_{1}$ ('Penglai Red') [58]. Cytological investigation of fertilization during hybridization between Patinopecten yessoensi (우) and Chlamys farreri ( $\left.\sigma^{\top}\right)$ reveals that both direct and reciprocal sperm normally penetrate the egg, a typical fertilization process. Heterologous sperm not only activates the egg, but also is involved in its genetic composition [59].

In fish, examples of interspecific hybridization include Cyprinus carpio rubrofuscus (우) $\times$ Cyprinus pellegrini pellegrini (ठ) [60], Oreochromis mossambicus (우) $\times$ Tilapia nilotica $\left(\sigma^{\top}\right)$ and its reciprocal cross [61,62], Silurus meridionalis (우)×Silurus asotus (ठ) [63], and Megalobrama terminalis (우)×Megalobrama amblycephala (ठ) and its reciprocal cross [64].

The Li GuiFeng research team at Zhongshan University has studied distant hybridization in mandarin fish. They directly crossed Siniperca kneri (우) with Siniperca chuatsi $\left(\sigma^{\top}\right)$ to obtain $F_{1}$ offspring. Selfing of the hybrid $F_{1}$ generation produced $\mathrm{F}_{2}$ progeny [65].

In amphibians, various cases of interspecific hybridization have been observed. Both direct and reciprocal cross between Rana nigromaculata and Rana plancyi fukienensis can yield small frogs [66], while only a few tadpoles are generated from the cross Rana guentheri (우) $\times$ Rana rugulosa (ठ) [16]. In contrast, healthy progeny are obtained from the reciprocal cross of Microhyla pulchra (우)× Microhyla ornata (ठ) [16]. Rana hubeiensis (우) $\times$ Rana nigromaculata $\left(\sigma^{\top}\right)$ hybrid offspring can develop into tadpoles and metamorphose into adult frogs [67].

Examples of interspecific equine hybrids are mules, the $\mathrm{F}_{1}$ offspring of Equus caballus (우) $\times$ Equus asinus ( $\sigma^{\top}$ ), and hinnies, the corresponding offspring of the reciprocal cross. Some female and male horses or mules are reproductively fertile [68]. Offsprings generated from the mating of Equus zebra (우) and Equus caballus (o), resemble Equus zebra, and the rusult of the reciprocal cross is the same.

An example of an interspecific bovine hybrid is the dzo, a cross between Bos taurus domestica (ठ) and Bos grunniens (우). Male dzo hybrids are infertile. In the Russian Altai region, males of different hybrid cattle varieties and female dzo mate are allowed to interbreed freely. Ideal dual-purpose milk and meat offspring have been obtained in this fashion [69].

The most representative example of sheep interspecific hybridization is that of Ovis ammon and Ovis aries. In addi- 
tion, hybridization between Ovis musimon and Ovis aries in the former Soviet Union has long been known, and Ovis ammon arkal has been crossed with Ovis merino to create new varieties [70].

Examples of interspecific hybridization in other mammals include the cross Panthera leo (우) $\times$ Panthera tigris $\left(\sigma^{\top}\right)$, which produces offspring called tigons, and the mating of Panthera tigris (우) with Panthera leo ( $\sigma^{\star}$ ) to yield the liger. Currently, about 30 living ligers exist worldwide, with female hybrids more likely to survive than males. Male hybrids are infertile, and are physically smaller in the second generation [71]. A leopon is the first filial generation off-

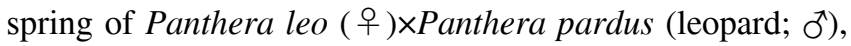
and was first bred in 1910 in an Indian zoo. Although leopons have bodies almost identical to Panthera leo, the males may have manes that are $20 \mathrm{~cm}$ long. A grolar bear is the hybrid offspring of a male Ursus arctos (grizzly bear) and a female Ursus maritimus (polar bear). Although the latter two species are genetically similar, they normally avoid each other in the wild. On April 16, 2006, an American hunter in the Canadian Arctic killed a grolar bear, the first documented naturally occurring hybrid. Prior to this discovery, hybrid bears were only observed in zoos. Follow-up reports have not appeared on these distant hybrid lineages.

\section{Formation of fish distant hybrid lineages}

Based on the above information, no $\mathrm{F}_{1}$ distant hybrid animal populations consisting of fertile males and females have been reported, except in fish. Although a few fertile female individuals have been detected among $\mathrm{F}_{1}$ hybrids of Ovis ammon $\times$ Ovis aries, Equus caballus $\times$ Equus asinus (mules), Bos taurus domestica $\times$ Bos grunniens (dzo), and Panthera leo $\times$ Panthera tigris (tigons), no fertile males have been discovered. The relative paucity of distant hybrid lineages in vertebrates other than fish may be attributed to several factors. First, influenced by the traditional view that inter-species reproductive isolating barriers cause infertility or reduced fertility in distant animal hybrids, long-term, systematic observation and research on $F_{1}$ distant hybrid offspring has been neglected. Second, although some early-stage fish offspring of distant hybridization, such as those in $F_{1}$ or $F_{2}$ generations, have poorly developed male sexual glands producing only watery sperm, the sperm is in fact viable and capable of producing offspring through fertilization. In other vertebrates, such apparent infertility has been accepted at face value without further investigation. Third, as an early-diverging vertebrate lineage, fish exhibit a lower degree of genetic differentiation than other vertebrates, enhancing distant hybrid survival rates. Fourth, many more species of fish are extant than other vertebrates (mammals, birds, reptiles, and amphibians), providing greater opportunities for distant hybridization to occur. Finally, many fish species undergo external fertilization, a reproductive feature amenable to distant hybridization testing and observation of embryonic development.

Distant hybridization is well studied in fish, the largest vertebrate group with more than 32000 species. Previous surveys [7,72-74], which summarize the chromosome data for 318 fish species, indicate that most fish possess an even number of chromosomes, with diploid chromosome counts of 44, 48, 50, and 100 predominating (Figure 1). Counts are normally distributed, with major peaks around $2 n=44,48$, and 50, and a smaller one at $2 n=100$. More specifically, 26

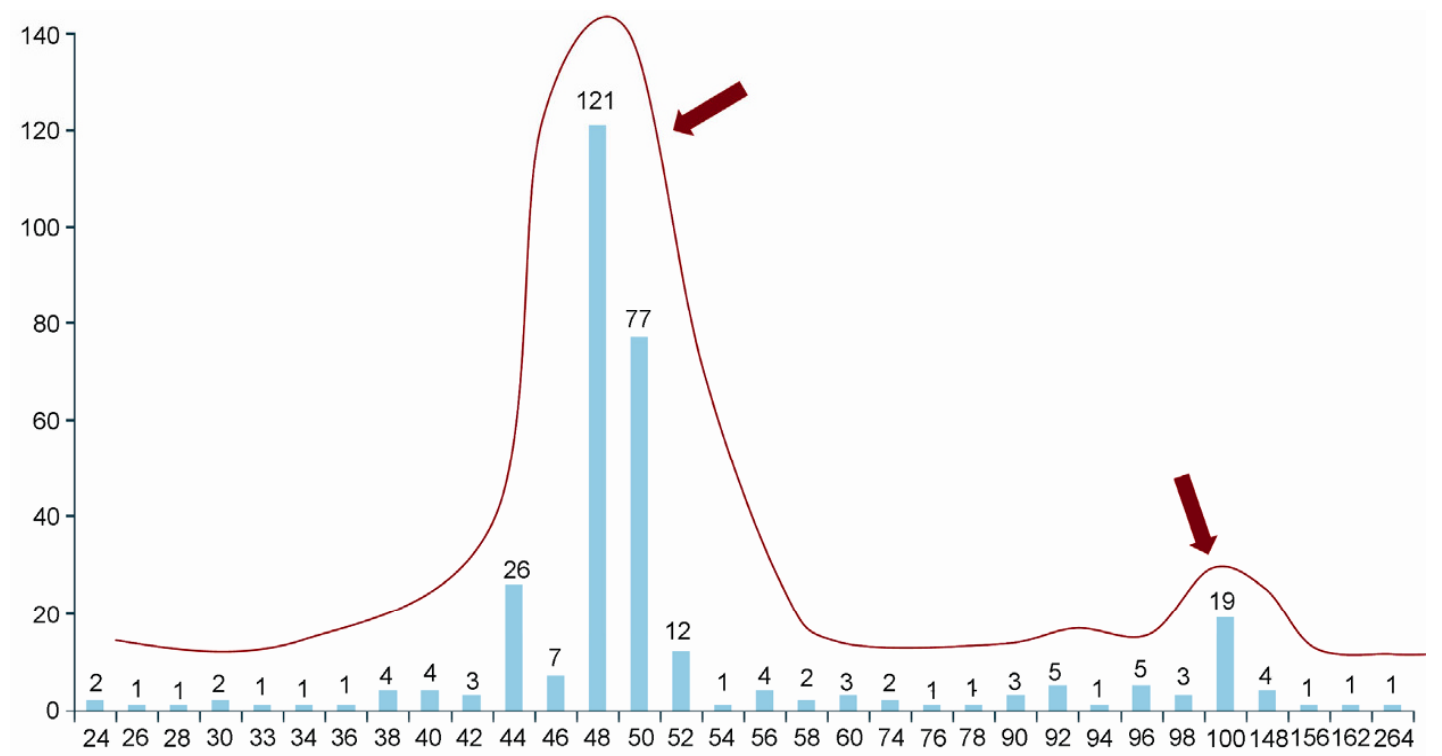

Figure 1 Chromosome number distribution of 318 fish species (slightly modified from Song et al. [74]). Chromosome and species numbers are indicated by horizontal and vertical axes, respectively; arrows indicate chromosome numbers with the highest frequencies. 
species have 44 chromosomes, 119 species have 48, 77 have 50, and 19 species possess 100 chromosomes. Two fish species, Liobagrus marginatus (Siluriformes) and Monopterus albus (Synbranchiformes), have the smallest number of chromosomes $(2 n=24)$, whereas Acipenser sinensis has the most $(2 n=264)$. Many fish species are polyploid or have chromosome numbers suggestive of past polyploidization. Given the large number of such species, some past polyploidization events were likely associated with distant hybridization. Because fish have a long evolutionary history, direct evidence of polyploid formation through distant hybridization is difficult to obtain; however, past polyploidization events can be inferred from gene copy number and other data. In addition, tetraploid distant hybrid lineages were successfully obtained in one previous study. Such studies provide research models and relevant evidence for research into the formation of new fish species through distant hybridization - of obvious relevance to the fields of biological evolution and fish breeding.

The formation of fish polyploids via distant hybridization is influenced not only by parental chromosome numbers, but also by compatibility and interaction of parental DNA, cytoplasm, and other relevant factors. The selection of parental fish with identical chromosome numbers for distant hybridization is conducive to proper chromosome pairing, coordination between parents, and distribution of genetic material in cells during mitosis and meiosis. On a cellular and molecular level, this compatibility is ultimately beneficial for common stable inheritance of genetic material. The use of parents with different chromosome numbers, which increases nuclear-nuclear and nuclear-cytoplasmic incompatibility between the two species, does not contribute to chromosome pairing or stable inheritance, but instead promotes processes such as those giving rise to retained maternal chromosomes and genetically variable autotetraploids.

The choice of parents for distant hybridization experiments requires consideration of chromosome number phylogenetic relationships, reproductive characteristics, shape, diet, growth rate, disease resistance, and other factors. When designing hybrid crosses, parents possessing different desirable traits are chosen to produce hybrids with a combination of excellent hybrid characteristics. For example, crosses involving Carassius auratus red var. and Cyprinus carpio must take into account their similar chromosome number $(2 n=100)$ and omnivorous diets, and that sexual maturation occurs in Carassius auratus at one year and in Cyprinus carpio at 1-2 years. Similarly, for hybridization of Carassius auratus red var. with Megalobrama amblycephala, considerations include their respective chromosome numbers ( $2 n=100$ and 48, respectively), and Carassius auratus red var. is omnivorous, while Megalobrama amblycephala is herbivorous diets, and the fact that Megalobrama amblycephala has an age of sexual maturity of 1-2 years. Megalobrama amblycephala and Erythroculter ilishaeformis hybrid combinations must take into consideration that parental chromosome numbers are $2 n=48$, Erythroculter ilishaeformis is carnivorous, and the age of sexual maturity in both species is 1-2 years. Ctenopharyngodon idellus and Megalobrama amblycephala hybridization must take into account the fact that both species have 48 chromosomes and are herbivorous, and that the age of sexual maturity in Ctenopharyngodon idellus is $4-5$ years. Selection of the appropriate parental combination and proper design of a distant hybridization study, with the goal of generating a long-term distant hybrid lineage, is not a trivial matter. If breeding bottlenecks and other problems are eliminated in $F_{1}$ and $F_{2}$ hybrid generations, a bisexual fertile lineage can be formed, enabling cross-breeding.

We have found, along with our colleagues, that the fate of polyploid fish formed during distant hybridization is closely linked to genetic relationships between parents. When the number of maternal chromosomes is greater than or equal to the number of paternal chromosomes, hybrids can survive easily [1]. Conversely, if paternal chromosomes are numerically dominant, hybrid viability is unlikely. And, under special circumstances, a very small number of natural gynogenetic offspring may be produced.

When both parents in a distant hybridization have the same chromosome number, hybrid triploids or diploids, but not tetraploids, can be easily obtained from the $F_{1}$ diploids; in subsequent generations, however, tetraploid fish lineages can be formed through fusion of unreduced gametes generated by the diploid hybrids. Via this distant hybridization pathway, diploid and tetraploid hybrid mating lineages can be formed along with other new and improved diploid and triploid fish (Figures 2 and 3). This approach has been applied to hybrid combinations involving members of different genera, such as Carassius auratus red var. (우)× Cyprinus carpio (ठ), Cyprinus carpio (우) $\times$ Carassius auratus red var. (ठ), and Megalobrama amblycephala (우)×Erythroculter ilishaeformis $\left({ }^{\star}\right)$, and their reciprocal cross. This approach also has been applied to hybrid combinations involving members of different subfamilies, such as Megalobrama amblycephala $($ 우 $) \times$ Xenocypris davidi $\left({ }^{\top}\right)$.

When distant hybridization is carried out between parents with different chromosome numbers, the resulting $F_{1}$ generation consists of tetraploid, triploid, and natural gynogenetic diploid hybrids. Self-crossing of the $\mathrm{F}_{1}$ tetraploid hybrids leads to $F_{2}$ and subsequent generation tetraploid lineages possessing genetic variation; these tetraploid fish are essentially autotetraploid through loss of the original paternal chromosome set, which was relatively small compared with the original maternal chromosome set (Figures 3 and 4). Examples of hybrid combinations in which this approach has been applied include Carassius auratus red var. (우) $\times$ Megalobrama amblycephala ( $\overbrace{}^{\top})$ in different subfamilies, Carassius auratus red var. (우) $\times$ Xenocypris davidi $\left({ }^{\top}\right)$, and Carassius auratus red var. (우)×Erythroculter ilishaeformis $\left(\sigma^{\top}\right)$. 


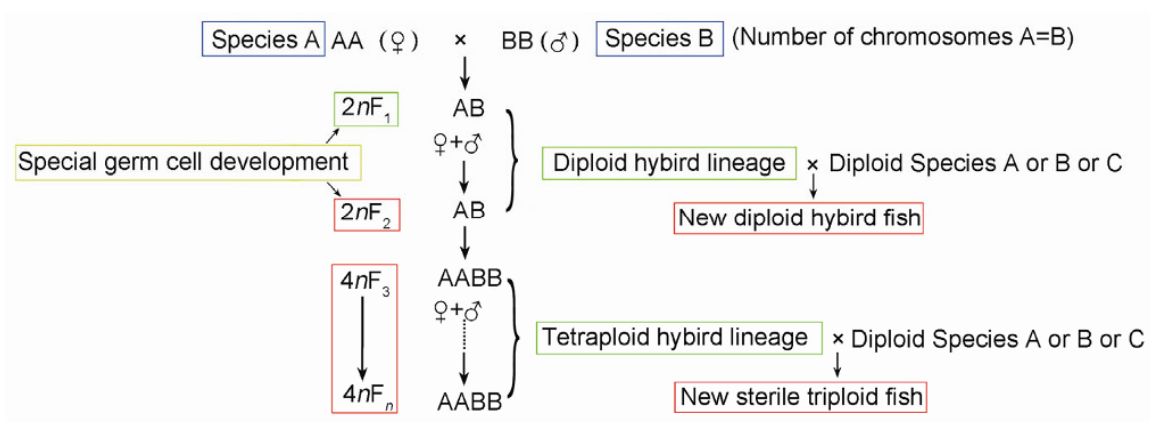

Figure 2 Distant hybridization with parents having identical chromosomal numbers and the application.

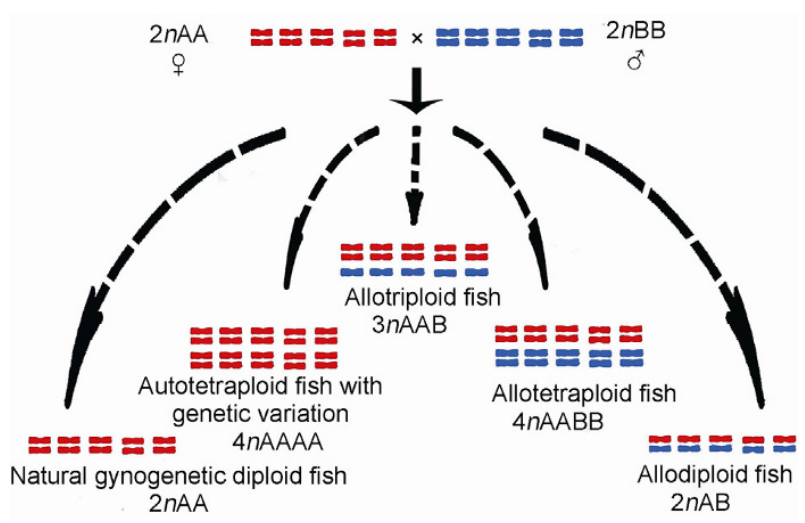

Figure 3 Schematic diagram illustrating the derivation of hybrids from different distant hybridization combinations. Red and blue indicate the different chromosomes from different parents. Through distant hybridization and subsequent selection, Carassius auratus red var. (AA, 우) $\times$ Cyprinus carpio $\left(\mathrm{BB},{ }^{\star}\right)$ can give rise to a $4 n \mathrm{AABB}$ allotetraploid lineage; while Carassius auratus red var. (AA, 우) $\times$ Megalobrama amblycephala $\left(\mathrm{BB}, \mathrm{\sigma}^{\top}\right)$ can produce a 4 nAAAA autotetraploid lineage, sterile allotriploid fish $(3 n \mathrm{AAB})$, and natural gynogenetic diploid fish $(2 n \mathrm{AA})$ lineage. Conversely, Megalobrama amblycephala (AA, 우) $\times$ Erythroculter ilishaeformis $\left(\mathrm{BB},{ }^{\top}\right)$ can be used to establish a new diploid fish $(2 n \mathrm{AB})$ lineage.

We have successfully generated and investigated a number of distant hybrid fish lineages (Table 1). We subsequently performed an additional series of distant hybridization experiments, which yielded new $F_{1}$ hybrids (Table 2). These studies have laid the groundwork for the future establishment of additional hybrid lineages.

Distant hybridization combinations involving parents with identical chromosome numbers are listed in Tables 1 and 2. Megalobrama amblycephala (우, Megalobrama) $\times$ Erythroculter ilishaeformis ( $\sigma^{\top}$, Culter) and its reciprocal cross, with each parent having 48 chromosomes and belonging to different genera, have already been bred to the third generation. Megalobrama amblycephala (우, Cultrinae) $\times$ Xenocypris davidi ( ${ }^{\top}$, Xenocyprininae), with parents' chromosomes (both $2 n=48$ ) from different subfamilies, has already produced $\mathrm{F}_{2}$ offspring. Four-year-old $\mathrm{F}_{1}$ hybrids of Ctenopharyngodon idellus (우, Leuciscinae) $\times$ Megalobrama amblycephala ( $\sigma^{\top}$, Cultrinae), another combination of $2 n=48$ parents across subfamilies, have been generated, but whether they can form a distant hybrid lineage remains to be researched. The intergeneric cross Carassius auratus red var. (우, Carassius) $\times$ Cyprinus carpio ( ${ }^{\top}$, Puntioplites) (both $2 n=100$ ) has already been established to 23 generations, and the combination of Cyprinus carpio (우) $\times$ Carassius auratus red var. $\left(\sigma^{\top}\right)$ has been developed into the $F_{2}$ generation. A subset of $\mathrm{F}_{2}$ female and male individuals from the combina-

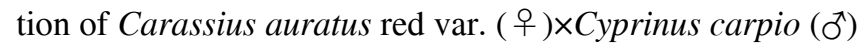
were able to ameiotically produce diploid eggs and sperm; they formed male and female $4 n \mathrm{AT}$ lineages in the course of $\mathrm{F}_{3}$ fertilization, laying the foundation for extension of the 4nAT lineage.

As shown in Tables 1 and 2, hybridizations between fish species with different chromosome numbers include Carassius auratus red var. (우, Cyprinae) $\times$ Megalobrama amblycephala (ơ, Cultrinae), Carassius auratus red var. (우, Cyprinae) $\times$ Erythroculter ilishaeformis (ō, Cultrinae), Carassius auratus red var. (우)×Xenocypris davidi (ð, Xenocyprininae), and Carassius auratus red var. (우) $\times$ Elopichthys bambusa (ð, Leuciscinae) and so on. An $\mathrm{F}_{1}$ allotetraploid $(4 n=148)$ population was produced from Carassius auratus red var. (우)×Megalobrama amblycephala $\left(\mathrm{O}^{\top}\right)$; breeding of $\mathrm{F}_{2}$ and subsequent generations led to the establishment of an autotetraploid $(4 n \mathrm{RB})$ lineage $\left(\mathrm{F}_{2}-\mathrm{F}_{8}, 4 n=200\right)$ with varied characteristics. Distant hybridization between Carassius auratus red var. (우) and Megalobrama amblycephala ( $\left.\sigma^{\star}\right)$ yielded some $F_{1}$ female and male individuals that were able to ameiotically produce diploid eggs $(2 n=100)$ and diploid sperm $(2 n=100)$; these individuals formed a female and male $4 n \mathrm{RB}$ lineage $(4 n=200)$ in the course of $F_{2}$ fertilization, laying the foundation for the lineage's extension. Additional distant hybridization crosses have been bred to the $F_{1}$ generation and are being cultivated to obtain $\mathrm{F}_{2}$ hybrids. To generate additional experimental data, crossing experiments will be conducted in the future between more distant lineages with different chromosome numbers, such as hybridization across orders or families.

Distant hybridization of parents with identical or differ- 
Table 1 Fish lineages established from distant hybridization

\begin{tabular}{|c|c|c|c|c|c|c|c|}
\hline \multirow{2}{*}{\multicolumn{2}{|c|}{ Genetic relationship }} & \multirow{2}{*}{$\begin{array}{c}\text { Serial } \\
\text { number }\end{array}$} & \multirow{2}{*}{ Hybridized combination } & \multicolumn{3}{|c|}{ Genetic algebra (ploidy/age at sexual maturity) } & \multirow{2}{*}{$\begin{array}{c}\text { The formation and } \\
\text { characteristics of } \\
\text { lineages }\end{array}$} \\
\hline & & & & $\mathrm{F}_{1}$ & $\mathrm{~F}_{2}$ & $\mathrm{~F}_{3}$ & \\
\hline \multirow{4}{*}{ Genus } & \multirow{4}{*}{$\begin{array}{l}\text { The parents } \\
\text { have identi- } \\
\text { cal chromo- } \\
\text { somal num- } \\
\text { bers }\end{array}$} & 1 & $\begin{array}{l}\text { Carassius auratus red var. } \\
\text { (우) } \times \text { Cyprinus carpio }\left({ }^{\top}\right) \\
\quad \text { 우 } 2 n=100 \times 2 n=1000^{\star}\end{array}$ & $\begin{array}{l}2 n=100 \\
(2 \text { years })\end{array}$ & $\begin{array}{c}2 n=100 \\
(2 \text { years })\end{array}$ & $\begin{array}{l}4 n=200 \\
(1 \text { year })\end{array}$ & $\begin{array}{c}\mathrm{F}_{3}-\mathrm{F}_{23} \\
(4 n=200)\end{array}$ \\
\hline & & 2 & $\begin{array}{c}\text { Cyprinus carpio } \\
\text { (우) } \times \text { Carassius auratus red } \\
\text { var. }\left(\bigcirc^{\star}\right) \\
\text { 우 } 2 n=100 \times 2 n=100 \overbrace{}^{\star}\end{array}$ & $\begin{array}{l}2 n=100 \\
(2 \text { years })\end{array}$ & $\begin{array}{l}2 n=100 \\
(2 \text { years })\end{array}$ & & $\begin{array}{c}\mathrm{F}_{1}-\mathrm{F}_{2} \\
(2 n=100)\end{array}$ \\
\hline & & 3 & $\begin{array}{c}\text { Megalobrama amblycephala } \\
\text { (우) } \times \text { Erythroculter ilishae- } \\
\text { formis }\left({ }^{\top}\right) \\
\text { 우 } 2 n=48 \times 2 n=48 ठ^{\star}\end{array}$ & $\begin{array}{c}2 n=48 \\
(2 \text { years })\end{array}$ & $\begin{array}{c}2 n=48 \\
(2 \text { years })\end{array}$ & $\begin{array}{c}4 n=96 ?^{\mathrm{a})} \\
\text { (to be detected) }\end{array}$ & $\begin{array}{c}\mathrm{F}_{1}-\mathrm{F}_{3} \\
(2 n=48 ; 4 n=?)\end{array}$ \\
\hline & & 4 & $\begin{array}{c}\text { Erythroculter ilishaeformis } \\
\text { (우 }) \times \text { Megalobrama ambly- } \\
\text { cephala }\left({ }^{\nwarrow}\right) \\
\text { 우 } 2 n=48 \times 2 n=48 ठ^{\star}\end{array}$ & $\begin{array}{c}2 n=48 \\
(4 \text { years) }\end{array}$ & $\begin{array}{c}2 n=48 \\
(2 \text { years })\end{array}$ & $\begin{array}{c}4 n=96 ? \\
\text { (to be detected) }\end{array}$ & $\begin{array}{c}\mathrm{F}_{1}-\mathrm{F}_{3} \\
(2 n=48 ; 4 n=?)\end{array}$ \\
\hline \multirow{2}{*}{ Subfamily } & $\begin{array}{l}\text { The parents } \\
\text { have identi- } \\
\text { cal chromo- } \\
\text { somal num- } \\
\text { bers }\end{array}$ & 1 & $\begin{array}{c}\text { Megalobrama amblycephala } \\
\text { (우) } \times \text { Xenocypris davidi }\left({ }^{\star}\right) \\
\text { 우 } 2 n=48 \times 2 n=48 ठ^{\star}\end{array}$ & $\begin{array}{c}2 n=48 \\
(2 \text { years })\end{array}$ & $\begin{array}{c}2 n=48 \\
(2 \text { years })\end{array}$ & & $\begin{array}{c}\mathrm{F}_{1}-\mathrm{F}_{2} \\
(2 n=48)\end{array}$ \\
\hline & $\begin{array}{l}\text { The parents } \\
\text { have differ- } \\
\text { ent chromo- } \\
\text { somal num- } \\
\text { bers }\end{array}$ & 2 & $\begin{array}{l}\text { Carassius auratus red var. } \\
\qquad \begin{array}{c}\text { (우) } \times \text { Megalobrama } \\
\text { amblycephala }\left(\circlearrowleft^{\star}\right) \\
\text { 우 } 2 n=100 \times 2 n=48 ठ^{\star}\end{array}\end{array}$ & $\begin{array}{l}4 n=148 \\
(2 \text { years })\end{array}$ & $\begin{array}{l}4 n=148 \\
(2 \text { years }) \\
4 n=200 \\
\text { (1 year) }\end{array}$ & $\begin{array}{l}4 n=148 \\
(2 \text { years) } \\
4 n=200 \\
(1 \text { year) }\end{array}$ & $\begin{array}{c}\mathrm{F}_{1}-\mathrm{F}_{8} \\
(4 n=148 ; 4 n=200)\end{array}$ \\
\hline
\end{tabular}

a) ?, the chromosome ploidy needs to be detected.

Table 2 Establishment of the fish distant hybrid $\mathrm{F}_{1}$

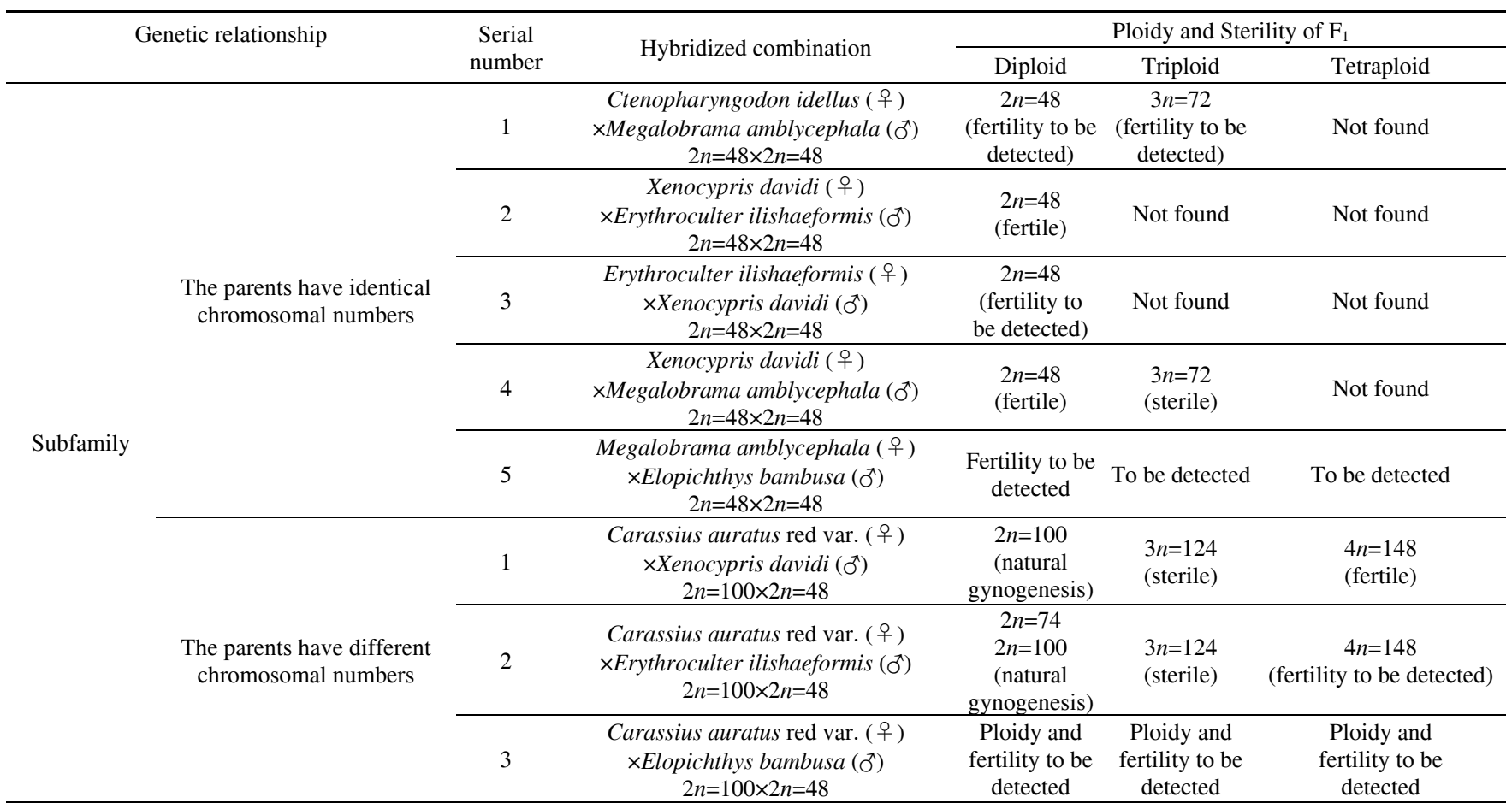

ing numbers of chromosomes can be used to obtain fish lineages of different ploidies (Figure 3 ). These results provide support for the hypothesis that distant hybridization plays an important role in the enhancement of fish chromosomal diversity.

Triploid fish cultivation offers many advantages. Be- 


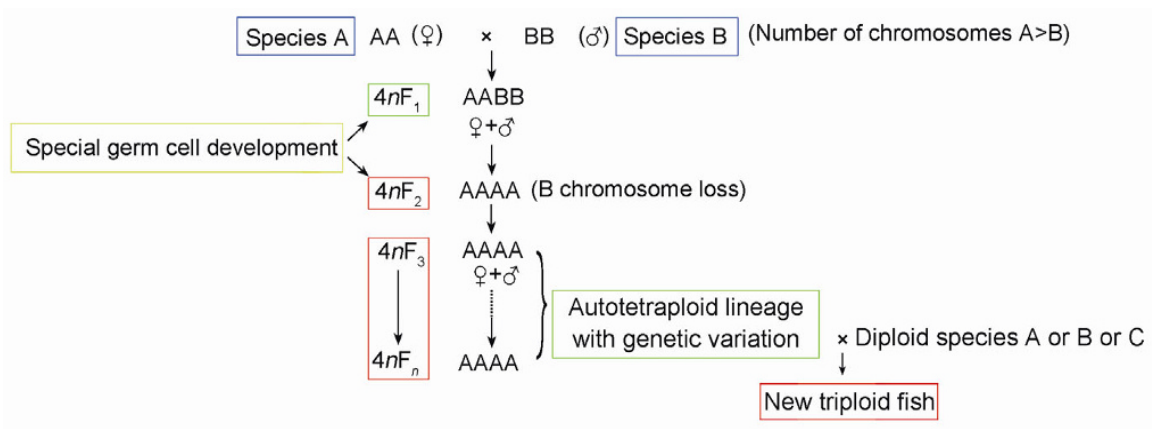

Figure 4 Distant hybridization with parents having different chromosomal numbers and the application.

cause they cannot breed, triploids do not contaminate natural fish germplasm resources and cause problems related to intellectual property rights protection. In addition, they have a potentially rapid growth rate, strong disease resistance, and good meat quality, which improves quality and yield, reduces or eliminates the use of medication, and lowers production costs. The development of infertile triploids from crosses of tetraploid and diploid fish is an ideal triploid fish production method.

The development of tetraploid fish has long been a focus of both domestic and foreign research. Norwegian researchers have used cytochalasin B to induce the formation of tetraploid steelhead (Oncorhynchus mykiss) [75], while Americans have used heat-shock induction to produce tetraploid catfish (Silurus asotus) [76] and tetraploid steelhead [77]. French scientists have applied two methods-hydrostatic pressure and heat shock-to induce tetraploid steelhead [78]. Chinese researchers have used a variety of methods: hydrostatic pressure treatment combined with cold shock to form a Carassius auratus transparent colored variety tetraploid [79], heat shock applied to Carassius auratus cuvieri (우)×Carassius auratus red var. ( $\sigma^{\top}$ ) hybrids [80] and to Megalobrama amblycephala [81] to induce tetraploids, and hydrostatic pressure to produce tetraploid Paralichthys olivaceus [82]. None of these methodscytochalasin B, hydrostatic pressure, heat shock, or chemical or physical techniques-have been successfully used to artificially produce fertile, bisexual tetraploid lineages. Nevertheless, useful experimental data and results have been obtained through these efforts.

The use of chemical or physical methods to artificially produce tetraploid fish differs in many respects from natural tetraploid fish generation, and is likely to result in mixed haploid-diploid or aneuploid individuals. These methods may also adversely affect important cytoplasmic factors in experimental fish. Such chromosomal and cytoplasmic changes are likely to lead to lowered fertility and survival rates.

The long-term research goal of our laboratory is the development of bisexual, fertile tetraploid fish lineages. We believe that the distant hybridization method is a suitable approach, as it mirrors tetraploid fish formation in nature.

\section{Genetic variability of fish distant hybrid lin- eages}

Hybridization and genetic introgression between species is a regular event during organismal evolution, especially in rapidly expanding biological populations, and promotes the formation and evolution of species [1,10,83-85]. In an analogous fashion, we introduced phenotypic and genotypic changes to RC, CR, RB, BT, and TB using distant hybridization and selection to produce $4 n \mathrm{AT}, 4 n \mathrm{RB}$, and $\mathrm{BT}$ lineages.

\subsection{Phenotypic and genotypic variation of $4 n \mathrm{AT}$ line- ages}

Our laboratory has established a long-term $4 n \mathrm{AT}$ lineage $\left(\mathrm{F}_{3}-\mathrm{F}_{23}, 4 n=200\right) \quad[1,41,42]$ and $4 n \mathrm{RB}$ lineage $\left(\mathrm{F}_{2}-\mathrm{F}_{8}\right.$, $4 n=200)$ [35]. The formation of these two different types of lineages represents two important methods for tetraploid fish production. Unlike colchicine- and hydrostatic-based methods, in which fertilized eggs of the same species are used, production of $4 n \mathrm{RB}(4 n=200)$ lineages involved two different parental species, having the genetic base. The $4 n \mathrm{AT}$ lineage $(4 n=200)$ and the $4 n \mathrm{RB}$ lineage $(4 n=200)$ have the same original female parent, Carassius auratus red var., but their original male parent is different. The two tetraploid fish lineages are genotypically and phenotypically similar, but with some obvious differences, and are of great importance for fish genetic breeding and biological evolutionary research.

A newly formed polyploid genome is unstable and undergoes rapid reconstruction to achieve more harmonious genomic coexistence in the nucleus $[85,86]$. One such example is that of Brassica, in which multiple genome rearrangements and segment deletions occurred within five generations following polyploid formation [87]. Genome structural changes may include deletion, insertion, duplication, translocation, and transposition events [86]. Through the use of chromosome-specific fluorescent in situ hybridi- 
zation (FISH) markers, at least nine reciprocal translocations have been detected in tetraploid Nicotiana tabacum, confirming that most tobacco chromosomes are associated with one of the two parental genomes [88]. Based on whole-genome in situ hybridization analysis, five reciprocal translocations have been found within the tetraploid Avena sativa genome, with as many as 18 detected in hexaploid Avena sativa [89]. Using FISH and other methods, we have confirmed the genetic parentage of $4 n \mathrm{AT}$ and verified the heterologous hybrid nature of these allotetraploid fish [1].

Through the examination of HoxC9a [90], Sox9a, Sox9b [91], and other related genes in $4 n \mathrm{AT}$, we found that the $4 n \mathrm{AT}$ lineage has inherited genetic material from both original parents: Carassius auratus red var. (maternal) and Cyprinus carpio. This shows that genetic material from different parents can simultaneously be inherited in tetraploid fish lineages.

In collaboration with the laboratory of Zhang YaPing at Yunnan University, we systematically studied liver tissue transcript gene mutation and genetic recombination phenomena in $\mathrm{RC}$ lineages (including $2 n \mathrm{RC}$ and $4 n \mathrm{AT}$ ). We uncovered evidence for recombination and verified the existence of genetic variation within $2 n \mathrm{RC} \mathrm{F}_{1}, \mathrm{~F}_{2}$, and $4 n \mathrm{AT}$ groups (data not published).

We have observed genetic variation and restructuring phenomenon not only at the transcriptional level, but also at the nuclear DNA level in many $F_{1}$ hybrids. For example, evidence for gene mutation and recombination has been found in the BT $\mathrm{F}_{1}$ and descendants, such as a HoxD9a recombination detected in $\mathrm{BT}_{1}$ hybrids [90].

Evidence for several nuclear DNA recombination events has been found in $4 n \mathrm{AT}$ lineage. First, HoxC9a genes of $4 n \mathrm{AT}$ are derived not only from Carassius auratus red var., but also include recombinant gene subtypes in intron regions. The nucleotide sequence of the first half of this subtype is consistent with Cyprinus carpio, and the second half matches the gene sequence in Carassius auratus red var. [92]. Second, the GnRH2 gene in the nuclear DNA of $4 n \mathrm{AT}$ has been shown to be recombined [93]. Finally, as inferred by BAC library construction and long PCR technology, guanine nucleotide-binding protein $G(I) / G(S) / G(O)$ subunit gamma-5, denticleless homolog, chemokine ( $C-X-C$ motif) receptor $7 b$, and phosphodiesterase $11 \mathrm{~A}$ have also experienced recombination (data not published).

Nuclear DNA recombination has been detected in $\mathrm{F}_{1}$ distant hybrid somatic cells (liver cells). This recombination cannot be owed to the exchange and restructuring of non-homologous (heterologous) chromosomes in meiotic germ cells, however, as the genetic material of $F_{1}$ somatic cells is not derived from fertilization of the hybrid. We propose the following explanation for the process of nuclear DNA recombination in $\mathrm{F}_{1}$ distant hybrid somatic cells. Distant hybrid somatic cell genetic material comes from different parental genomes; thus, genes from the two different genomes may produce DNA endonucleases in this particular hybridization environment. The cut DNA can be exchanged and re-ligated via DNA recombination repair mechanisms, producing recombinant DNA. The question arises: why is DNA of $F_{1}$ distant hybrid somatic cells more likely to recombine? We speculate that long-term separation of the two parental genomes is deleterious to their coexistence in the distant hybrid somatic cells. Consequently, the two different genomes recombine, producing genetic variation that is also readily passed on to offspring. The distant hybridization DNA recombination trend in the original $4 n \mathrm{AT}$ lineage is also conducive to the formation of diploid fish, ultimately leading to a genetically modified fish with doubled genetic material, the same as a tetraploid. Further research is needed to determine what kinds of genes are more likely to exchange, and in what proportions. In distant hybrid lineages beyond the $F_{1}$ generation, recombined DNA may include recombinant DNA in somatic cells and heterologous recombinant DNA between non-homologous chromosomes. More in-depth research remains to be conducted.

Because of the different parental genomes, somatic cell DNA recombination is easily detectable in fish distant hybrids. It is unclear whether somatic cell DNA recombination is discernible from nuclear transcript levels in more closely related fish hybrids. Because of the high genetic similarity of self-crossing parents or hybrids of closely related species, such genetic material-if it exists—is not easily identified. Further research is needed in this area.

Genotype alterations may lead to changes in performance. Increased cell volume is generally observed in polyploids along with genome doubling and increases in genetic material. Polyploid plants and animals have evolved various strategies to compensate for increased cell size $[94,95]$. Polyploid plants possess the same number of cells as diploids, but have larger organs and body sizes.

$4 n \mathrm{AT}$ morphological traits differ in various ways from those of the original parents. For example, average ratios of standard length/height and head length/snout length of the $4 n \mathrm{AT}$ lineage are intermediate between that of its original parents. Carassius auratus red var. lacking a palpus and Cyprinus carpio possessing this structure, while the length of $4 \mathrm{nAT}$ palpus is between that of its original parents. In $4 n \mathrm{AT}$, numbers of gill rakes and lateral scales as well as the arrangement of pharyngeal teeth are also intermediate between the original parents. The standard length/head length of the $4 n \mathrm{AT}$ lineage however, is smaller in $4 n \mathrm{AT}$ than in the original parents $[1,41]$.

Differences are also noted among diploid, triploid, and tetraploid fish at the cellular level. As ploidy levels increase, nuclear and cellular diameters of erythrocytes and other blood cells increase, as well as the percentage of unusual erythrocytes [96,97]. In 4nAT, erythrocyte nuclei appear particularly dumbbell-shaped [98]. 


\subsection{Phenotypic and genotypic changes in the $4 n \mathrm{RB}$ lineage}

The $4 n \mathrm{RB} \mathrm{F}_{1}$ hybrid was obtained from a cross between diploid Carassius auratus red var. and diploid Megalobrama amblycephala, while the $\mathrm{F}_{2}$ was obtained from an $4 n \mathrm{RB} \mathrm{F}_{1}$ self-cross and showed genetic variation. $4 n \mathrm{RB} \mathrm{F}_{1}$ $(4 n=148)$ is an allotetraploid containing two sets of chromosomes from Carassius auratus red var. and two sets from Megalobrama amblycephala. $4 n \mathrm{RB} \quad \mathrm{F}_{2}\left(\mathrm{~F}_{2}-\mathrm{F}_{8}, 4 n=200\right)$ however, is an autotetraploid containing four sets of chromosomes from Carassius auratus red var.

In terms of appearance, the body color of Carassius auratus red var. is red, while that of Megalobrama amblycephala is silvery white, and neither have barbels. In contrast, $4 n \mathrm{RB}$ has a gray body and a pair of distinct barbels-obvious evidence of genetic changes. As demonstrated by these results, fish with barbels can be obtained from distant hybridization of parents lacking barbels. In addition, these results also provide distant hybridization evidence that fish with barbels are hybrids of fish without barbels.

With respect to genotype, $4 n \mathrm{RB}$ showed significant genetic variation. A centromere-specific repetitive sequence of Carassius auratus red var. was used as a FISH probe to identify Carassius auratus red var. and Megalobrama amblycephala segments in the genomes of $4 n \mathrm{RB} \mathrm{F}_{1}$ and $4 n \mathrm{RB}$ $\mathrm{F}_{2}$. Chromosomes of Carassius auratus red var. showed a fluorescence signal, whereas those of Megalobrama amblycephala did not. The 100 chromosomes of $4 n \mathrm{RB} \mathrm{F}_{1}$ that were derived from Carassius auratus red var. were also fluorescently marked. $4 n \mathrm{RB} \mathrm{F}_{2}$ would be expected to have 200 fluorescently marked chromosomes; in fact, only 100 chromosomes displayed a fluorescence signal, indicating the presence of significant genetic variation with respect to the other 100 chromosomes. Furthermore, the 5S rDNA gene cluster in $4 n \mathrm{RB} \mathrm{F}_{1}$ and $4 n \mathrm{RB} \mathrm{F}_{2}$ displayed significant genetic variation with respect to recombination, composition, and arrangement. Three types of 5S rDNA structural units (types I, II, and III) are present in Carassius auratus red var., with only one (type IV) found in Megalobrama amblycephala. These four types of 5S rDNA structural units differ in sequence length and base composition. $4 n \mathrm{RB} \mathrm{F}_{1}$ inherited only the three $5 \mathrm{~S}$ rDNA structural units belonging to the female parent; the paternal type had been completely lost, indicating that the $4 n \mathrm{RB} \mathrm{F}_{1}$ genome was an obvious variation. Different $5 \mathrm{~S}$ rDNA gene clusters are typically distributed on different chromosomes or different chromosomal regions. In the $4 n \mathrm{RB} \mathrm{F}_{2}$ genome, we found that types I and II were connected together to form a dimeric structure. A similar dimeric structure was not found in Carassius auratus red var. and $4 n \mathrm{RB} \mathrm{F}_{1}$ genomes. This result demonstrates that $4 n \mathrm{RB} \mathrm{F}_{2}$ chromosomes have undergone reorganization, leading to the $5 \mathrm{~S}$ rDNA combinations on the two different chromosomal regions.
We comparatively analyzed phenotypes and genotypes of a $4 n$ AT $(4 n=200)$ lineage and the $4 n \mathrm{RB}(4 n=200)$ lineage. The primary morphological difference between these two types of tetraploid fish is related to the arrangement of pharyngeal teeth: $4 n \mathrm{AT}$ has two rows, whereas the $4 n \mathrm{RB}$ has only one [99]. With respect to genotype, transcriptome analysis uncovered similarities and differences between the two lineages.

The two tetraploid fish lineages have the same chromosome number $(4 n=200)$ and original female parent (Carassius auratus red var.), but different male parents: Cyprinus carpio and Megalobrama amblycephala. As a consequence, analysis of genes expressed in fish liver revealed differences between the two tetraploids, and that more genes were expressed in the $4 n \mathrm{RB}$ lineage than in $4 n \mathrm{AT}$.

We compared distributions of expressed genes according to function. Expressed genes associated with the functional categories of "cells (cell part)", "organelles (organelle)", and "macromolecular compounds (macromolecular complex)" were more heavily represented in the liver tissue of the $4 n \mathrm{RB}$ lineage than in $4 n \mathrm{AT}$. In the "cell (cell function)" category, fewer expressed genes were found in the $4 n \mathrm{RB}$ lineage than in the $4 n \mathrm{AT}$ lineage. These results indicate that the two tetraploid fish lineages have different functional gene expression profiles.

With regard to co-expressed genes, differences exist in the nucleotide sequences of various genes in the two tetraploid fish. One example with obvious differences is the highly expressed homologous gene bhlhe40 (1881 bp), which encodes a basic helix-loop-helix protein widely expressed in various tissues and thought to be involved in the control of cell differentiation. Sequence differences between the two tetraploids can be exploited for the development of molecular markers useful for identification and functional analysis.

Study of the formation of different fish ploidies is of great importance to the fields of fish evolutionary genetics, breeding, and biotechnology research. Distant hybridization between parents with the same number of chromosomes can generate two different types of tetraploids in two different processes: bisexual female allotetraploid fish lineages (e.g., $4 n$ AT lineage, $4 n=200)$ and autotetraploid fish lineages with genetic variation (e.g., $4 n$ RB lineage, $4 n=200$ ). With respect to fish breeding research, their formation indicates that two different types of tetraploid fish lineages can be generated through these two pathways, providing an abundance of tetraploid parents for the preparation of triploid fish via mating between different ploidy levels. With regard to biological evolution research, their formation indicates that the evolution of polyploid fish has likely occurred in nature through these two pathways. These two hybridization approaches provide good model systems for exploring the relationship between distant hybridization and polyploidization. 


\subsection{Changes in phenotype and genotype of the BT lin- eage}

$F_{1}$ and $F_{2}$ generations of diploid $\mathrm{BT}$ possess lateral line scales and dorsal and anal fins that are intermediate in shape and quantity to those of the two parents. Conversely, the hybrids have more pelvic fins than either parent [100].

With respect to genetic structure, the $\mathrm{BT} \mathrm{F}_{1}$ and $\mathrm{TB} \mathrm{F}_{1}$ generation inherited parental-specific ITS 1 , whereas parental-specific ITS 1 has been lost in some $\mathrm{F}_{2}$ individuals. In the first hybrid generation, $2 n \mathrm{BT} \mathrm{F}_{1}, 3 n \mathrm{BT} \mathrm{F}_{1}$, and $2 n \mathrm{~TB} \mathrm{~F}_{1}$ all inherited simultaneously expressed parental-specific $18 \mathrm{~S}$ rRNA genes. With regard to the $\mathrm{F}_{2}$ generation of $2 n \mathrm{BT}$, some possessed both parental 18S rRNA genes, and these genes were expressed; some inherited both genes, but only the specific 18S rRNA of Megalobrama amblycephala was expressed; and others carried and expressed only the $18 \mathrm{~S}$ rRNA gene of Erythroculter ilishaeformis. Concerning the $\mathrm{F}_{2}$ generation of $2 n \mathrm{~TB}$, some inherited and expressed both $18 \mathrm{~S}$ rRNA genes; some inherited the original parental-specific 18S rRNA genes, but only expressed the specific 18S rRNA of Megalobrama amblycephala; some others inherited both but only expressed the specific 18S rRNA of Erythroculter ilishaeformis; and others only inherited and expressed the 18S rRNA of Megalobrama amblycephala [100].

The 5S rDNA coding region, the A frame, internal element (IE), and $\mathrm{C}$ frame, including the internal transcriptional control area, are all present in the 5S rDNA sequence of Megalobrama amblycephala, Erythroculter ilishaeformis, and their hybrids. The 5S rDNA sequences of Megalobrama amblycephala and Erythroculter ilishaeformis are highly conserved. In $2 n \mathrm{BT} \mathrm{F}_{2}, 2 n \mathrm{~TB} \mathrm{~F}_{1}$ and $\mathrm{F}_{2}$ type-II $5 \mathrm{~S}$ rDNA, a $\mathrm{T} \rightarrow \mathrm{C}$ transition is present at nucleotide position 73 . A G $\rightarrow \mathrm{A}$ transition occurs at that locus in $2 n \mathrm{BT} \mathrm{F}_{1}$ type-I $5 \mathrm{~S}$ rDNA [100].

A comparative analysis of NTS (non-transcribed intergenic spacer) sequences in Megalobrama amblycephala, Erythroculter ilishaeformis, $2 n \mathrm{BT} \mathrm{F}_{1}$ and $\mathrm{F}_{2}$ generations, $3 n \mathrm{BT}$, and $2 n \mathrm{~TB} \mathrm{~F}_{1}$ and $\mathrm{F}_{2}$ generations uncovered a number of base substitutions and insertion sequences. Compared with parental NTS-I sequences, a polyA sequence is inserted in the NTS-I sequence of filial generations; in $2 n \mathrm{~TB}$, the short variation sequence CATTTT is also inserted. Sequence variation between NTS-II of Erythroculter ilishaeformis and NTS-II of filial generations consists mainly of single nucleotide substitutions or deletions [100].

A comparison of Hox gene sequences in $\mathrm{BT} \mathrm{F}_{1}$ and its parents revealed various nucleotide substitutions and evidence of recombination. Exchanges and recombination had occurred in intron regions of the BT $\mathrm{F}_{1}$ HoxD $9 a$ gene; the first portion of its intron sequence was consistent with $\mathrm{Meg}$ alobrama amblycephala, and the latter portion matched Erythroculter ilishaeformis. This exchange restructuring phenomenon in BT serves as a source of genetic variation and genetic diversity, and provides important experimental data regarding the ability of hybrids to adapt to the environment as well as the process of biological evolution [90].

\section{Application of fish distant hybridization lin- eages}

The formation of distant hybrid lineages is very useful for studies of biological evolution and genetic breeding. Alterations in a hybrid's genotype produce phenotypic changes and introduce hybrid vigor passed on to the next generation. Fish with hybrid advantage can be produced by crossing genetically improved individuals belonging to heterologous diploid lineages derived from parental species of identical chromosome number with related diploid fish (Figures 2 and 3). Examples obtained in this fashion include the generation of $\mathrm{BT}($ 우) $\times$ Megalobrama amblycephala (ठ) (BTB) having various desirable traits through the backcrossing of superior female parents selected from BT lineages with male Megalobrama amblycephala individuals. Other types of high-quality hybrid fish can be developed by breeding superior male or female Megalobrama amblycephala or Erythroculter ilishaeformis individuals with BT and TB lineages. In addition, diploid heterologous hybridization lineages can be used to breed bisexual, fertile allotetraploid fish lineages. Allotetraploid fish can be mated with diploid fish to form sterile triploids, as exemplified by crossings of the $4 n$ AT lineage with diploid Carassius cuvieri and diploid Cyprinus carpio. This technique can be used on a large scale to produce fast-growing, strongly resistant, sterile triploid crucian carp (Carassius cuvieri) and triploid carp. We have also used distant hybridization and gynogenesis to develop improved tetraploid fish populations; after mating them with associated diploid fish, large-scale production was used to obtain a variety of improved triploid fish with superior characteristics [101].

Distant hybridization between parents having differing chromosome numbers to generate TB hybrids results in the direct formation in the $F_{1}$ generation of sterile allotriploid fish as well as an allotetraploid hybrid lineage $\left(4 n \mathrm{RB} \mathrm{F}_{1}\right.$, $4 n=148$ ); subsequent selfing of this allotetraploid lineage leads to the formation of bisexual, fertile tetraploid fish lineages with genetic variation $\left(\mathrm{F}_{2}-\mathrm{F}_{8}, 4 n=200\right)$. These latter lineages can be mated with diploid fish on a large scale to develop triploid fish. Natural gynogenetic diploid fish with genetic variation characteristics of Carassius auratus red var. can also be formed in the first generation of RB distant hybrids; subsequent selfing leads to a diploid Carassius auratus red var. lineage with genetic mutation that can be mated with other diploid fish to form diploid hybrids with heterosis (Figure 3). In addition, $4 n \mathrm{RB} \mathrm{F}_{1}$ females can backcross with Megalobrama amblycephala males to obtain 
$5 n \mathrm{RB}(5 n=172)$ males, and females of Carassius auratus red var. can be backcrossed with $4 n \mathrm{RB}^{\mathrm{F}} \mathrm{F}_{1}$ hybrids to yield another new $5 n \mathrm{RB}$ lineage $(5 n=198)$ [35].

The development of sterile transgenic triploid fish is one of the most effective ways to eliminate potential ecological risks posed by transgenic fish. The laboratory of Zhu ZuoYan has made outstanding contributions in this area [102,103]. To minimize the shortcomings of artificially induced triploid fish and control potential risks posed by transgenic fish introduction, the Institute of Hydrobiology of the Chinese Academy of Sciences has joined with Hunan Normal University to carry out hybridization experiments between Cyprinus carpio and 4nAT; a transgenic triploid fish showing fast growth, efficient feed conversion, and good breeding traits has been developed via hybridization of fish with differing ploidy levels [104].

This work was supported by the Major International Cooperation Projects of the National Natural Science Foundation of China (31210103918), Training Program of the Major Research Plan of the National Natural Science Foundation of China (91331105), the National Key Basic Research Program of China (2012CB722305), the National High Technology Research and Development Program of China (2011AA100403), the Cooperative Innovation Center of Engineering and New Products for Developmental Biology of Hunan Province (20134486), and the Construct Program of the Key Discipline in Hunan Province and China.

1 Liu SJ. Distant hybridization leads to different ploidy fishes. Sci China Life Sci, 2010, 53: 416-425

2 Liu ZD. Genetics (in Chinese). Beijing: Higher Education Press, 1991

3 Gui JF, Zhou L. Genetic basis and breeding application on clonal diversity and dual reproduction modes in polyploid Carassius auratus gibelio. Sci China Life Sci, 2010, 53: 409-415

4 Xiao J, Zou TM, Chen YB, Chen L, Liu SJ, Tao M, Zhang C, Zhao RR, Zhou Y, Long Y, You CP, Yan JP, Liu Y. Coexistence of diploid, triploid and tetraploid crucian carp (Carassius auratus) in natural waters. BioMed Center Genetics, 2011, 12: e20

5 Nolte AW, Freyhof J, Stemshorn KC, Tautz D. An invasive lineage of sculpins, Cottus sp. (Pisces, Teleostei) in the Rhine with new habitat adaptations has originated from hybridization between old phylogeographic groups. Proc Royal Soc B Biol Sci, 2005, 272: 2379-2387

6 Meyer A, Salzburger W, Schartl M. Hybrid origin of a swordtail species (Teleostei: Xiphophorus clemenciae) driven by sexual selection. Mol Ecol, 2006, 15: 721-730

7 Saitoh K, Chen WJ, Mayden RL. Extensive hybridization and tetrapolyploidy in spined loach fish. Mol Phylogenet Evol, 2010, 56: 1001-1010

8 Grant PR, Grant BR, Petren K. Hybridization in the recent past. Am Nat, 2005, 166: 56-57

9 Mallet J. Hybrid speciation. Nature, 2007, 446: 279-283

10 Zhu X. Discussion about the fertilization process of animal hybridization (in Chinese). Chin Sci Bull, 1961, 7: 1-7

11 Loeb J. The Fertilization of the Egg of the Sea-Urchin by the Sperm of the Starfish. Berkeley: The University Press, 1903

12 The Yangtze River Fisheries Research Institute. Artificial propagation of fish (in Chinese). Beijing: Agriculture Press, 1973. 83

13 The students of 1959 session of aquaculture specialty in Shanghai Ocean University. Pond Fish Culture Lectures (in Chinese). Beijing: Higher Education Press, 1959. 172

14 Yu JH, Xia DQ, Yang H, He YH, Wu TT. Morphology of the proge- nies of Oreochromis aurea( 우)×Sinipperca chuatai( $\left.{ }^{\circledR}\right)$ (in Chinese). J Fish China, 2003, 27: 431-435

15 Yang H, Xia DQ, Liu L, Wu TT. Studies on hereditary relationship between Oreochromis aurea (우), Siniperca chuatsi (ð`) and their offspring (in Chinese). J Fish China, 2004, 28: 594-598

16 Zhu X. Research on Guangzhou frogs interbreed (in Chinese). Nat Sci Zhongshan Univ, 1934, 6: 219-262

17 Fisheries experimental station of Beijing. A preliminary summary of fish introduction and hybridization test (in Chinese). Freshwater Fisheries, 1973, 3: 15-18

18 Guo HQ, Tu FM, Wang BX, Shou XZ. Preliminary observation of Ctenopharyngodon idellus and Aristichthy nobilis artificial hybridization and their offspring (in Chinese). Chin J Zool, 1966, 4: $188-189,154$

19 The Biology Department of Hunan normal university. Preliminary results of hybridization test of Ctenopharyngodon idellus (ठ), Aristichthy nobilis (우) and fertilization cytology study (Abstract) (in Chinese). Freshwater Fisheries, 1973, 6: 2-4

20 He WG, Xie LH, Li TL, Liu SJ, Xiao J, Hu J, Wang J, Qin QB, Liu Y. The formation of diploid and triploid hybrids of grass carp (우) xblunt snout bream $\left(\sigma^{\star}\right)$ and their 5S rDNA analysis. BioMed Center Genet, 2013, 14: 110

21 Ye YZ, Wu QJ, Chen RD. Studies on cytology of crosses between grass carp and carp-asynchronization between nucleus and cytoplasm in distant hybridization of fishes (in Chinese). Acta Hydrobiol Sin, 1989, 13: 234-239

22 Liu SY, Li SW. On the Erythrocyte nucleus size and DNA contents of Ctenopharyngodon idellus, Megalobrama terminalis and $\mathrm{F}_{1}$ hybrid of the triploid (in Chinese). J Genet Genom, 1987, 14: 142-148

23 Liu SY. Studies of insemination cytology in hybridization between grass carp and preshwater bream (in Chinese). J Fish China, 1987, 11: 225-232

24 Liu Y, Chen SQ, Wang YX. The fertilization cytology research of Megalobrama terminalis sperm and Mylopharyngodon piceus eggs (in Chinese). Acta Hydrobiol Sin, 1981, 7: 329-340

25 Chen SQ. Investigation on the inter-subfamily hybridization Mylopharyngodon piceus (우) $\times$ Megalobrama terminalis( $\left.0^{\top}\right)$ I. Comparative cytogenetic study on Mylopharyngodon piceus (우)×Mega- lobrama terminalis $\left(\sigma^{\top}\right)$ and their $\mathrm{F}_{1}$ generation(in Chinese). J Hunan Normal Univ (Natural Science Edition), 1984, 7: 71-80

26 Wu WX, Lin LA, Xu DY. A tetraploid hybrids-(Cyprinus carpio L.) $\times($ Ctenopharyngodon idellus V.) (in Chinese). Acta Hydrobiol Sin, 1981, 7: 433-436

27 Wu WX, Li CW, Liu GA,Xu DY, Liu CS, Xie JY, Shan CX. Studies on tetraploid hybrid between red carp (Cyprinus carpio) and grass carp (Ctenopharyngodon idellus) and its backcross triploid (in Chinese). Acta Hydrobiol Sin, 1988, 12: 355-363

28 Liu GA, Wu WX, Lin LA, Xu DY, Zhen YG. A cytological study on the cross fertilization of red common carp with grass carp (in Chinese). J Fish China, 1987, 11: 17-21

$29 \mathrm{Li} \mathrm{CW}$. Electrophoretic analysis on the serum protein of Xingguo red carp, grass carp and their hybrid $\mathrm{F}_{1}$ (in Chinese). Freshwater Fisheries, 1991, 6: 12-14

30 Pan GB. Preliminary studies on the hybrid between Hypophthalmichthys molitrix and Megalobrama amblycephala (in Chinese). Freshwater Fisheries, 1987, 1: 17-19

31 Zhu LF, Gui JF, Liang SC, Jiang YG. Isozyme expression of distant hybridization offspring and artificial triploid in silver carp (Hypophthalmichthys molitrix) (in Chinese). Acta Hydrobiol Sin, 1993, (4): 293-297

32 The Yangtze river fisheries research institute, Xiamen fisheries college. The situation of freshwater fish breeding improved varieties breeding research and basic theory (in Chinese). Chin J Zool, 1975, (1): 43-45

33 Gui JF, Liang SC, Zhu LF, Sun JM, Jiang YG. Cytogenetic analysis of developmental difference in hybrid embryos between reciprocal crosses in distant hybridization of fishes (in Chinese). Zool Res, 1993, 14: $171-177$ 
34 Wang H, Liu RZ. The study of the hybridization of Hypophthalmichthys molitrix (우) Cyprinus carpio (ठ) species (in Chinese). J Nanjing Univ (Natural Science Edition), 1986, 22: 87-94

35 Liu SJ, Qin QB, Xiao J, Lu WT, Shen JM, Li W, Liu JF, Duan W, Zhang C, Tao M, Zhao RR, Yan JP, Liu Y. The formation of the polyploid hybrids from different subfamily fish crossing and its evolutionary significance. Genetics, 2007, 176: 1023-1034

36 Hu J, Liu SJ, Xiao J, Zhou Y, You CP, He WG, Zhao RR, Song C, Liu Y. Characteristics of diploid and triploid hybrids derived from female Megalobrama amblycephala Yih $\times$ male Xenocypris davidi Bleeker. Aquaculture, 2012, 364-365: 157-164

37 Che QF, Wang KM. Embryo brain stem structure observation of hybrid offspring between black bone chickens and guinea fowl (Numida meleagris) and measurement of its morphological indexes (in Chinese). J Anhui Agricult Sci, 2007, 35: 4-20

38 Mr DE column uz, leaf, tome, the Czech Republic even nie. Distant hybridization of animals and plants (in Chinese). Moscow: The Soviet Academy of Sciences Press, 1960. 291-306

39 McGovern PT. The effect of maternal immunity on the survival of goat $\times$ sheep hybrid embryos. J Reprod Fertil, 1973, 34: 215-220

40 Bmy napolitano. Some genetic problems in distant hybridization of Ovis aries and Capra hircus (in Chinese). Translated by Qin Wen. Sci Agricult Sin, 1961, (5): 53-56

41 Liu SJ, Liu Y, Zhou GJ, Zhang XJ, Luo C, Feng H, He XX, Zhu GH, Yang $\mathrm{H}$. The formation of tetraploid stocks of red crucian carpxcommon carp hybrids as an effect of interspecific hybridization. Aquaculture, 2001, 192: 171-186

42 Sun YD, Liu SJ, Zhang C, Li JZ, Huang WR, Zhang J, Luo KK, Zhou GJ, Liu Y. The Chromosome Number and Gonadal Structure of $\mathrm{F}_{9}-\mathrm{F}_{11}$ Allotetraploid Crucian-carp (in Chinese). Acta Genet Sin, 2003, 30: 414-418

43 Jiang YG, Liang SC, Chen BD, Yu HX, Shan SX, Yang DL, Lin SE, Shen GQ. Biological effect of Heterologous sperm on gynogenetic offspring in Carassius auratus gibelio (in Chinese). Acta Hydrobiol Sin, 1983, 8: 1-16

44 The Yangtze river fisheries research institute. An experimental report on backcross breeding of big head (Aristichthy nobilis) (우) $\times\left(\right.$ Hypophthalmichthys molitrix 우 $\times$ Aristichthy nobilis $\left.{ }^{\top}\right)$ (ठ) (in Chinese). Acta Genet Sin, 1975, 2: 144-152

45 Zhang ZY, Qiu QR, Hu M, Lin KH. Observations on the embryonic and larval development of the backcross hybrids of Aristichthys nobilis (우) $\times\left(\right.$ Hypophthalmichthys molitrix 우 $\times$ Aristichthys nobilis $\left.ठ^{\top}\right)\left(ठ^{\top}\right)$ (in Chinese). Acta Zool Sin, 1979, 25: 108-117

46 Biology department of Shanxi University, Taiyuan forestry and water conservancy station. A preliminary study on Parabramis pekinensis and Megalobrama terminalis artificial hybridization (in Chinese). Freshwater Fisheries, 1973, 5: 6-9

47 Yin YH, Han X, Han RZ. A preliminary study on Parabramis pekinensis and Megalobrama terminalis artificial hybridization (in Chinese). Genet Commun, 1974, 3: 36-38

48 Foshan district administration of Guangdong province. Megalobrama amblycephala and Parabramis pekinensis hybrid (in Chinese). Fish Sci Tech Inf, 1975, 4: 18-19

49 Lin YH. A comparative of the karyotypes in Chinese bream, herbivorous bream and their hybrid (in Chinese). Zool Res, 1984, 5: 65-66

50 The Breeding Room of the Yangtze River Fisheries Research Institute, Animal Biology Department of Wuhan University Teaching and Research Section. The preliminary study on several kinds of economic fish and the hybrid chromosome (in Chinese). Freshwater Fisheries, 1975, 2: 11-13

51 Fisheries Research Institute of Nanchang. Mylopharyngodon piceus and Ctenopharyngodon idellus hybrid breeding (in Chinese). Freshwater Fisheries, 1973, 1: 10-14

52 Jiang SG, Li JE, Qu YJ, Zhong CG, Yu DH. Studies on hybridization between silver bream (Rhabdosargus sarba) (우) and red bream (Pagrosomus major) (ơ) (in Chinese). Marine Sci, 1997, 5: 33-38

$53 \mathrm{Qu}$ YJ, Li JE, Zhou HT. Larval development and growth of intergeneric crossing of Sparidae fishes (in Chinese). J Fish Sci China, 2000,
7: 110-112

54 Zhang YZ, Tan YJ, Ou YH. China Pond Aquaculture Science (in Chinese). Beijing: Science Press, 1990. 89-120

55 Fisheries Research Institute of Guangxi for Chamber Dace Group. Using hybrid improve the cold resistance of dace (in Chinese). Freshwater Fisheries, 1980, 6: 26

56 Zhang JX, Liu XF, Wang ZX, Jin GQ. A comparative study on the karyotype among the hybrid fish (Sinilabeo decorus $\delta^{\top} \times$ Cirrhinus molitorella 우) and its parental fishes (in Chinese). Acta Hydrobiol Sin, 1984, 8: 313-322

57 Li SF, Yan B, Cai WQ, Li TY, Jia JH, Zhang YH. Evaluation of growth, salt tolerance and parents' heterosis contribution reciprocal $\mathrm{F}_{2}$ between Oreochromis niloticus and Sarotherodon melanotheron (in Chinese). J Fish China, 2008, 32: 335-341

58 Liu GX, Bao ZM, Hu JJ, Wang S, Yao B, Zhan AB. ISSR analysis of two species of scallop (Chlamys farreri, C. nobilis) and their intra-and inter-species mating descendants (in Chinese). Period Ocean Univ China, 2006, 4: 71-75

59 Yang AG, Wang QY, Liu ZH, Zhang Y. Cytological observation on cross fertilization of Chlamys farreri and Patinopecten yessoensi with fluorescent microscope (in Chinese). Marine Fish Res, 2002, 23: $1-4$

60 Zhang JS, Ma ZB, Wang CS. Research and utilization of $F_{1}$ between Cyprinus carpio rubrofuscus (우) and Cpellegrini pellegrini (o) (in Chinese). Freshwater Fishery, 1979, 2: 14-18

61 Liu RZ, Wang H, Chen JP. Investigation on sexual difference composition of serum protein of two tilapia and their hybrid (in Chinese). J Fish China, 1985, 9: 265-273

62 Wan SL, Huang EC, Qi CX, Wei YS. The comparison experiment of Oreochromis mossambicus and Tilapia nilotica reproduction performance (in Chinese). Freshwater Fishery, 1987, 2: 15-16

63 Wang ZM, Zou GW, Luo XZ, Pan GB, Yang GQ, Zhu CZ. A study on hybridization between Silurus meridionalis (우) and Silurusmeri asotus (ठ) (in Chinese). Freshwater Fishery, 2004, 34: 41-43

64 Yang HY, Li SF, Zou SM. A primary study on inheritance of morphological traits from Megalobrarma amblycephala, Megalobrama terminalis to their reciprocal hybrids $\left(\mathrm{F}_{1}\right)$ (in Chinese). J Shanghai Fish Univ, 2002, 32: 3-5

65 Lu X, Sun JJ, Wang HF, Luo D, Hou XC, Liu LZ, Li GF. Observations on embryonic development of reciprocal hybrids of Siniperca kneri Garman $\times$ Siniperca chuatsi Basilewsky and $\mathrm{F}_{2}$ of $S$. kneri (우) $\times S$. chuatsi (ठ) $\mathrm{F}_{1}$ (in Chinese). China Fish Sci, 2013, 20: 975-981

66 Ding HB. Hybridization experiments of Peking Anurans (in Chinese). J Fujian Normal Univ (Natural Science Edition), 1956, 2: 1-7

67 Liu CW, Luo C, Chen XC. Hybridization experiments of four species of frogs (in Chinese). J Nat Sci Hunan Normal Univ, 1990, 13: 286-288

68 Zong EZ, Fan GS, Yin HF, Wang BL, Zhang CF, Sun MJ, Jiao S. A study on the chromosomes of interspecific $\mathrm{F}_{2}$ hybrids between horse and ass (in Chinese). Sci Agricult Sin, 1985, 83-85

69 Eph, Eph Ivanovna. The Hybridization Between Species of Bos grunniens and Large Footed Animals (in Chinese). Moscow: The Soviet academy of sciences press, 1960. 340-357

70 Bunch TD, Foote WC, and Spillett JJ. Sheep-goat hybrid karyotypes. Theriogenology, 1976, 6: 379-385

71 Gray AP. Mammalians Hybrids Commonwealth. Cambridge: Cambridge University Press, 1954

72 Yu XJ, Zhou T, Li YC, Li K. Chromosomes of Chinese Fresh-water Fishes (in Chinese). Beijing: Science Press, 1989

73 Li YJ, Qian C, Ying J, Gao M, Gao YC, Liu B, Wang YS. The chromosome sets stability of hybrid progeny in different ploidy loach (in Chinese). J Dalian Ocean Univ, 2012, 4: 326-332

74 Song C, Liu SJ, Xiao J, He WG, Zhou Y, Qin QB, Zhang C, Liu Y. Polyploid organisms. Sci China Life Sci, 2012, 55: 301-311

75 Refstie T. Tetraploid rainbow trout produced by cytochalasin B. Aquaculture, 1981, 25: 51-58

76 Bidwell CA, Chfisman CL, Libey G. Polyploidy induced by heat 
shock in channel catfish. Aquaculture, 1985, 5: 25-32

77 Thorgaard GH, Jazwin ME, Stier AR. Polyploidy induced by heat shock in rainbow trout. T Am Fish Soc, 1981, 110: 546-550

78 Chourrout D, Chevassus B, Krieg F, Happe A, Burger G, Renard P. Production of second generation triploid and tetraploid rainbow trout by mating tetraploid males and diploid females-Potential of tetraploid fish. Theor Appl Genet, 1986, 72: 193-206

79 Gui JF, Sun JM, Liang SC, Huang WY, Jiang YG. Studies on genome manipulation in fish II. Tetraploidy induced by hydrostatic pressure treatment and combination of hydrostatic pressure and cold treatments in transparent colored crucian carp (in Chinese). Acta Hydrobiol Sin, 1991, 15: 333-342, 393-394

80 Chen MR, Yang XQ, Yu XM, Chen HX, Yi YL, Liu HQ. Chromosome ploidy manipulation of allptetraploids and their fertility in Japanese phytophagous crucian carp (JPCC) (우)×red crucian carp (RCC) (ठ) (in Chinese). Acta Hydrobiol Sin, 1997, 21: 197-206

81 Zou SM, Li SF, Cai WQ, Zhao JL, Yang HY. Establishment of fertile tetraploid population of bluntsnout bream. Aquaculture, 2004, 238: 155-164

82 Li WL, Chen SL, Ji XS, Xie MS, Xu Y, Deng H. Induction and identification of tetraploid fry in Cynoglossus semilaevis (in Chinese). China Fish Sci, 2012, 19: 196-201

83 Liu SJ, Cao YC, He XX, Li JZ, Liu Y. The formation of tetraploid hybrids of common carp with red crucian carp and evolutionary significance of tetraploidization in vertebrate (in Chinese). Eng Sci, 2001, 3: 33-41

84 Seehausen O. Hybridization and adaptive radiation. Trends Ecol Evol, 2004, 19: 198-207

85 Comai L. The advantages and disadvantages of being polyploidy. Nat Rev Genet, 2005, 6: 836-846

86 Chen ZJ, Ni ZF. Mechanisms of genomic rearrangements and gene expression changes in plant polyploids. Bioessays, 2006, 28: 240-252

87 Song K, Lu P, Tang K, Osborn TC. Rapid genome change in synthetic polyploids of Brassica and its implications for polyploid evolution. Proc Natl Acad Sci USA, 1995, 92: 7719-7723

88 Kenton A, Parokonny AS, Gleba YY, Bennett MD. Characterization of the Nicotiana tabacum L. genome by molecular cytogenetics. Mol Genet Genom, 1993, 240: 159-169

89 Jellen EN, Gill BS, Cox TS. Genomic in situ hybridization differentiates between $\mathrm{A} / \mathrm{D}$ and $\mathrm{C}$-genome chromatin and detects intergenomic translocations in polyploid oat species (genus Avena). Genome, 1994, 37: 613-618

90 Song ZY. The microsatellite research and Hox evolution of the ge- netic research of Erythroculter ilishaeformis (우)×Megalobrama amblycephala ( $\left.\sigma^{\star}\right)$ hybrids $F_{1}$ and its parents (in Chinese). Dissertation for Master's Degree. Changsha: Hunan Normal University, 2013

91 Liu JF, Liu SJ, Tao M, Li W, Liu Y. Isolation and expression analysis of testicular type sox $9 \mathrm{~b}$ in allotetraploid fish. Marine Biotechnol, 2007, 9: 329-334

92 Zou L. Research on the evolution of the Hox genes of allotetraploid Crucian-carp and its concerned parents (in Chinese). Dissertation for Master's Degree. Changsha: Hunan Normal University, 2012

93 Wang D. Studies on the expression of different ploidy fish reproductive gene HPG axis on the mechanism of sex determination (in Chinese). Dissertation for Doctoral Degree. Changsha: Hunan Normal University, 2013

94 Mable BK. 'Why polyploidy is rarer in animals than in plants': myths and mechanisms. Biol J Linn Soc, 2004, 82: 453-466

95 Gregory TR, Mable BK. Polyploidy in animals. In: Gregory, ed. The Evolution of the Genome. San Diego: Elsevier, 2005. 427-517

96 Liu Q, Wang YQ, Liu SJ, Guo XH, Luo KK, Zhang C, Liu Y. A comparative study on different ploidy cyprinids blood (in Chinese). Prog Nat Sci, 2004, 14: 1111-1117

97 Lu WT, Liu SJ, Long Y, Tao M, Zhang C, Wang J, Xiao J, Chen S, Liu JH, Liu Y. Comparative study on the erythrocytes of the polyploidy hybrids from various fish subfamily crossings. Cell Tissue Res, 2009, 336: 159-163

98 Liu SJ, Sun YD, Zhou GJ, Zhang XJ, Liu Y. The mature gonads of allotetraploid crucian-carp group and ultrastructural observation of red blood cell (in Chinese). Prog Nat Sci, 2003, 13: 194-197

99 Liu W. The morphological characteristics study of Pharyngeal teeth and hypopharyngeal about several kinds of fish under the distant hybrid strains (in Chinese). Dissertation for Master's Degree. Changsha: Hunan Normal University, 2013

100 Xiao J. Establishment of hybrid strains between blunt snout bream and topmouth culter and their genetic characteristic research (in Chinese). Dissertation for Doctoral Degree. Changsha: Hunan Normal University, 2013

101 Chen S, Wang J, Liu SJ, Qin QB, Xiao J, Duan W, Luo KK, Liu JH, Liu Y. Biological characteristics of an improved triploid crucian carp. Sci China Life Sci, 2009, 52: 733-738

$102 \mathrm{Hu}$ W, Wang YP, Zhu ZY. Progress in the evaluation of transgenic fish for possible ecological risk and its containment strategies. Sci China Life Sci, 2007, 50: 573-579

$103 \mathrm{Hu} \mathrm{W}$, Zhu ZY. Integration mechanisms of transgenes and population fitness of $G H$ transgenic fish. Sci China Life Sci, 2010, 53: 401-408

104 Yu F, Xiao J, Liang XY.Liu SJ, Zhou GJ, Luo KK, Liu Y, Hu W, Wang YP, Zhu ZY. Rapid growth and sterility of growth hormone gene transgenic triploid carp. Chin Sci Bull, 2011, 56: 1679-1684

Open Access This article is distributed under the terms of the Creative Commons Attribution License which permits any use, distribution, and reproduction in any medium, provided the original author(s) and source are credited. 